\title{
Adaptation of a gas cogeneration system used in power industry to drive inland waterway transport unit
}

Cogeneration systems are mainly used in industrial power plants (combined heat and power plants), but based on the analysis carried out in this publication, that suitably adapted and selected devices will be able on board of ships. A number of arguments have been obtained for using the indicated gas engine in a vessel. The cogeneration system guarantees high overall efficiency, as shown in the example of the cogeneration unit under study, for which the value of general efficiency was above 80\%. In addition, the use of natural gas as a fuel could ensure a significant reduction in the amount of toxic compounds emitted to the atmosphere, especially nitrogen oxides (2-3 times) and smog (dust with PM10) around 25 times than standard limits. The use of natural gas as a fuel guarantees similar dynamic parameters as with the use of standard fuels.

Key words: cogeneration, propulsion, natural gas, energy, inland waterway transport

\section{Introduction}

The transport sector is one of the key branches of the national economy and plays an increasingly important role in its development every year. It has a stimulating effect on the market and together with a well-developed transport network it creates an integrated system of a smooth flow of people and goods $[3,5,9]$.

Emerging road, rail, air and water connections create new opportunities and perspectives, making individual regions of the world better communicated. The efficient flow of goods and services generates, in turn, higher profits, thus creating prospects for further development of this sector. The main factors influencing the evolution and any changes in transport are: globalization, consumerism and striving to improve the comfort of life.

When discussing the transport sector, one should remember about the ecological aspect associated with its functioning, focusing primarily on the attention of designers and manufacturers, as well as users and legislative institutions on the combustion engine, which is the most popular means of transport.

In many countries, in the near future, there will be a boom for the transport industry. New challenges are also being taken in Poland. One of them is the comprehensive revitalization of river infrastructure in order to develop inland waterway transport $[13,15]$. This is a signal to undertake a series of activities, among which a significant place is taken up by the intensification of research into the sustainable use of energy. In this group of studies, an important role will be played by research into the combustion propulsion of vessels in the aspect of improving efficiency while using alternative fuels.

Sustainable development in this area may involve the use of useful energy for the drive and part of the energy wasted to supply various devices with electric and thermal energy. In turn, the use of alternative fuels (in the form of CNG and LNG), e.g. natural gas, would be a specific frame improving the environmental efficiency of the drive $[1,6$, $9,12,14]$.
Design and research experiences in this field flow directly from other areas of activities, such as energy or mining industry, where high-efficiency cogeneration systems confirm the existence of the possibility of beneficial production and use of mechanical, electrical and thermal energy while reducing the emission of harmful substances. The internal combustion engines tested in these areas can be used as engines for potential means of transport as a source of energy for heating and air-conditioning systems of this unit and as a source of electric energy for own means of transport. The use of a cogeneration system allows for effective use of all the above-described types of energy.

\section{Use of cogeneration system in a vessel as a research problem}

The research problem described in this publication is the evaluation of the cogeneration system used in power plant industry as an alternative source of propulsion for typical technical solutions currently used in vessels. This activity is the result of investment plans related to the revitalization of river infrastructure. Poland is a country that should develop this type of transport, if only due to the existence of water systems, in the basins of the two largest rivers Vistula and Odra (Fig. 1), extending properly throughout the country. These rivers form combined communication networks with a total length of $3655 \mathrm{~km}[5,15]$.

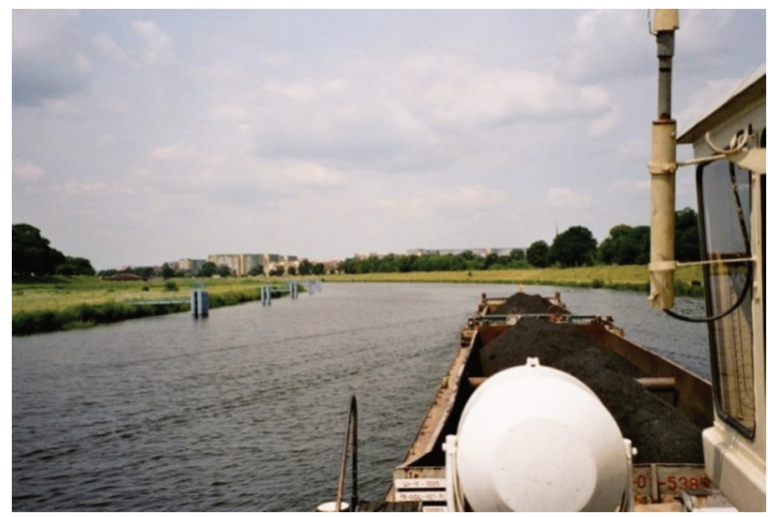

Fig. 1. One of the views of the Odra river 
The development of river infrastructure can largely unload the congested road transport system in Poland. The main advantage of inland transport is low energy consumption. Water transport is useful in the transport of oversized goods, where it does not interfere with other types of rolling stock and does not create restrictions for other users. Water transport is covered by regulations regarding the emission of toxic substances, which imposes an obligation to constantly search for structural solutions that meet the accepted standards.

Water transport is currently the least appreciated and widespread type of transport in our country. This is not a simple undertaking, due to fluctuations in the level of waterways, lack of investment on potential water routes and depleted technical infrastructure used for this type of transport. There are inland water transport modes for passengers and goods. A special case is the transport of goods, during which the barge used for transport does not have its own drive and pushers or tugs are used to overcome distances.

The development of waterways depends on the conditions of natural rivers and water reservoirs. The costeffectiveness of using waterways depends on their capacity and this is strictly dependent on the speed of vessels, the type of cargo and load capacity of a given ship and the required distance that particular ships would have to keep on a specified water course.

The propulsion system of the watercraft consists mainly of the mechanical energy source, which is usually the diesel internal combustion engine, as well as the transmission that transmits the torque obtained as a result of the propulsion engine operation, which in turn converts the obtained energy into rotation of the propeller, setting the vessel in motion $[3,5]$. In figure 2 . there is an example of a propulsion system used in a ship and parameters characteristic for a given part of the system.

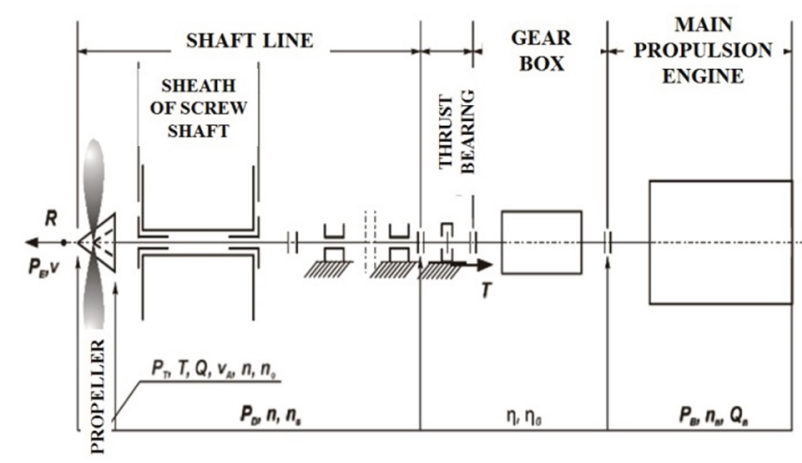

Fig. 2. The propulsion system of a vessel [5]. Main propulsion engine $\left(P_{B}\right.$ - power generated, $n_{n}$ - engine speed, $Q_{n}$ - heat delivered; Gear $\left(\eta_{e}-\right.$ efficiency of the drive system, $\eta_{G}$ - efficiency of the shaft lines); Shaft line $\left(\mathrm{P}_{\mathrm{D}}\right.$ - power delivered to the propeller, $\mathrm{n}-$ shaft rotation speed); Propeller $\left(\mathrm{P}_{\mathrm{T}}-\right.$ thrust power, $\mathrm{T}-$ thrust, $\mathrm{Q}-$ torque on the cone, $\mathrm{v}_{\mathrm{A}}-$ speed, $\mathrm{n}_{\mathrm{s}}-$ propeller speed, $\mathrm{R}$ - towing resistance, $\mathrm{P}_{\mathrm{E}}-$ ship towing power)

Due to the fact that transport plays a key role in the modern world, strict requirements are set before it, which define the framework of its functioning and development. This in turn imposes on individual states, their government agencies, state-owned enterprises, private companies, concerns, the obligation to search for new concepts, technolo- gies and solutions in accordance with applicable international arrangements, legal acts, technical and environmental standards. The above-mentioned requirements are to improve the living conditions, reduce the negative impact of transport on the natural environment, increase the level of safety in transport.

All of this focuses on the idea of sustainable transport, which means a balance between mobility, energy resources and pollution emissions. In this way, in terms of transport equivalence, it is reasonable to refer to the problem of low energy efficiency to cogeneration issues. The associated process of generating energy in transport units, via cogeneration systems, will undoubtedly contribute to reducing the emission of toxic compounds [7, 12].

The heat generated in the engine is usually a by-product. Thanks to cogeneration, this heat can be used for heating purposes (e.g. heating of rooms, cabins, decks on a watercraft, providing hot utility water on such a unit), it can be used for air conditioning or cooling purposes of a transport unit, where, e.g. absorption chiller powered with hot water, coming from the engine cooling systems, you can generate the so-called ice water. The mechanical energy generated basically for the unit's propulsion needs can be converted into a synchronic generator coupled with the engine for electricity and used more efficiently than in road transport, e.g. for lighting the premises in a transport unit, supplying measurement systems, etc. [12 ].

\section{Research and results}

\subsection{Research object}

The research object was the CUMMINSgas turbine, which together with the synchronous generator STAMFORD, formed the basis of the energy system at EC Muchobor-Wroclaw City, belonging to the Wroclaw Heat and Power Plant Complex KOGENERACJA S.A. Thanks to courtesy and with the consent of KOGENERACJA S.A., research was carried out and data from the daily reports of the cogeneration aggregate were obtained, which were used for analyzes covered by this publication. The owner of the unit - KOGENERACJA S.A., uses the mentioned unit as a source of electricity and heat for the needs of clients supplied from EC Muchobor. The present research was aimed at recommending this type of engine to drive a floating transport unit.

The tested HE-CG1400-GZ cogeneration gas unit (Fig. 3) consists of:

- CUMMINS four-stroke, turbocharged gas engine with spark ignition, providing electrical power up to 1435 $\mathrm{kW}$ at a rotational speed of $1500 \mathrm{rpm}$;

- STAMFORD synchronous generator with voltage 400/ $230 \mathrm{~V}$ and frequency $50 \mathrm{~Hz}$.

The gas path is connected to the main shut-off valve and other gas flow control elements. The fuel/gas flow and engine speed control system are all with the generator set.

Natural gas was used as a fuel. An important property of most gaseous fuels during the combustion process is the ability to create a homogeneous mixture, which is responsible for the proper course of the process. In addition, gaseous fuels are characterized by wide flammability ranges compared to petrol and diesel. They also have more hydro- 
gen than carbon in their composition, which results in a reduced emission of $\mathrm{CO}_{2}$ to the environment.

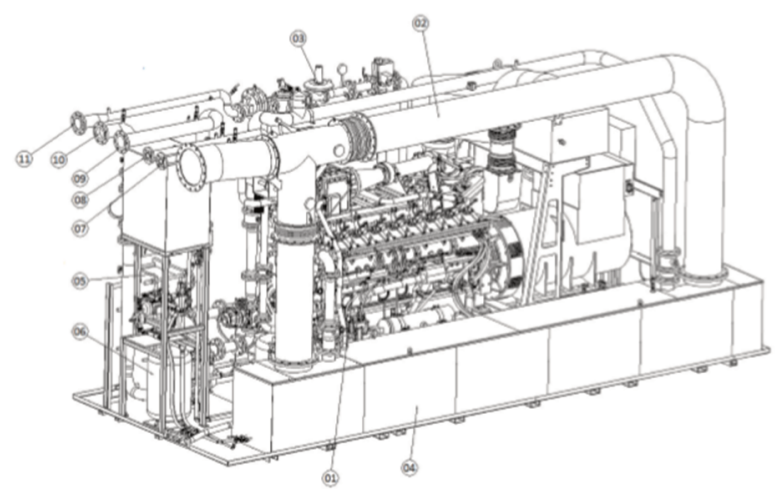

Fig. 3. View of the cogeneration gas system [16]. 01 - HE-EC-1400/1560CG1400-GZ unit, 02 - Exhaust gas bypass, 03 - Gas path, 04 - Exhaust gas heat exchanger, 05 - Plate heat exchanger, 06 - Collection vessel, 07 LT circulation outlet LT, 08 - LT circuit inlet, 09 - HT circuit outlet, 10 HT circuit inlet, 11 - Gas inlet, Motor cooling circuit (HT); The mixture cooling circuit (LT); Coolant temperatures, circuits: HT (engine), LT (intercooler)

Gaseous fuels are also characterized by a high methane number corresponding to resistance to knocking combustion in the engine. The value in question indicates the percentage share of methane in a given fuel, in turn the higher the share of methane, the more efficient the engine can be. Nevertheless, the methane number does not fully determine the efficiency of the system. Important parameters affecting the usefulness of the mixture in the combustion process are: range of fire limits, burning speed, energy of ignition, chemical composition, air demand, heating value $[4,6,8]$.

Because of differ in mentioned properties not every gas will work as an appropriate fuel in a cogeneration system. The given values depend on each other, hence knowing the chemical composition of the gas, the best air demand can be determined, which in turn in connection with the amount of heat release during combustion of the mixture determines the demand for a specific level of calorific value. In order to obtain the expected energy effect, a sufficient volume of the mixture must be supplied to the cylinder, which depends on the composition of the fuel and the amount of air. Often the amount of fuel-air mixture exceeds the engine's construction volume. Then it is necessary to use the recharge of the mixture in order to obtain the required power of the system. The growing interest in this type of fuels results from the reduced emission of pollutants during combustion of the mixture and similar parameters to petroleum products $[4,10,11]$. Fuel for this engine is a depleted gas/air mixture with a coefficient of $\lambda>1$. Two turbochargers were used to obtain the required mechanical power, one for each side of the engine. The compressed mixture passing through the intercooler, is cooled to the right temperature and then goes to the individual cylinders. The amount of mixture is dosed through the throttle regulator. The mechanical energy of the motor is transmitted to the generator by means of a clutch, whereas the thermal energy can be recovered or dissipated via an external cooler.

\subsection{Methodology of research implementation, data and results}

The assessment of the cogeneration system consists in the determination of electrical, thermal and total efficiency. In this way, it is possible to assess the suitability of the tested set for use in specific conditions - Table 1 .

Table 1. Sources of measurements

\begin{tabular}{|c|c|}
\hline Parameter & Method \\
\hline Electric power of unit & \multirow{2}{*}{ Electricity meter readings } \\
\hline Power factor & \\
\hline Gas flow & \multirow{3}{*}{$\begin{array}{l}\text { Gas meter readings at the reduction and } \\
\text { measuring station }\end{array}$} \\
\hline Gas temperature & \\
\hline Gas pressure & \\
\hline Calorific value & $\begin{array}{l}\text { According to the physicochemical analysis of } \\
\text { the gas sample } \\
\text { performed on order of unit owner }\end{array}$ \\
\hline $\begin{array}{l}\text { Coolant temperature - } \\
\text { return side }\end{array}$ & \multirow{2}{*}{ Parameters readings at the operator station } \\
\hline $\begin{array}{l}\text { Temperature - coolant } \\
\text { supply side }\end{array}$ & \\
\hline Heating water flow rate & $\begin{array}{l}\text { Parameters readings at the operator station - } \\
\text { ultrasonic flow meter on the machine hall }\end{array}$ \\
\hline Thermal power & $\begin{array}{c}\text { Thermal energy meter readings - temperature } \\
\text { and flow }\end{array}$ \\
\hline
\end{tabular}

The following relationships were used to calculate the efficiency of a cogeneration unit [2]:

- electrical efficiency of the system $\eta_{E}[\%]$

$$
\eta_{E}=\frac{P_{E}}{E_{G}}=\frac{P_{E}}{V_{G} \times W d} \times 100 \%
$$

- thermal efficiency of the system $\eta_{c}[\%]$

$$
\eta_{C}=\frac{Q_{E}}{E_{G}}=\frac{Q_{E}}{V_{G} \times W d} \times 100 \%
$$

- overall system efficiency $\eta_{\circ}[\%]$

$$
\eta_{0}=\frac{P_{E}+Q_{E}}{E_{G}}=\frac{P_{E}+Q_{E}}{V_{G} \times W d} \times 100 \%
$$
ble 2 .

During the tests the following data were recorded - Ta-

Table 2. Measurement results

\begin{tabular}{|l|c|c|c|c|}
\hline \multirow{2}{*}{ Parameter } & \multirow{2}{*}{ Unit } & \multicolumn{3}{c|}{ Load } \\
\cline { 3 - 5 } & & $50 \%$ & $75 \%$ & $100 \%$ \\
\hline Gas temperature & ${ }^{\circ} \mathrm{C}$ & 6.8 & 4.2 & 4.5 \\
\hline $\begin{array}{l}\text { Heating water temperature }- \\
\text { power supply side }\end{array}$ & ${ }^{\circ} \mathrm{C}$ & 85.2 & 84.6 & 85.3 \\
\hline $\begin{array}{l}\text { Heating water temperature }- \\
\text { return side }\end{array}$ & ${ }^{\circ} \mathrm{C}$ & 63.7 & 50.7 & 66,6 \\
\hline Gas pressure & $\mathrm{kPa}$ & 388 & 383 & 387 \\
\hline Gas flow rate & $\mathrm{Nm}{ }^{3} / \mathrm{h}$ & 190 & 261 & 340 \\
\hline Heating water flow rate & $\mathrm{m}^{3} / \mathrm{h}$ & 37 & 29 & 67 \\
\hline Thermal power & $\mathrm{kW}$ & 926 & 1156 & 1459 \\
\hline Electric power & $\mathrm{kW}$ & 703 & 1055 & 1405 \\
\hline
\end{tabular}


However, in the Table 3 the results of calculations of energy effects were included.

Table 3. Calculation results

\begin{tabular}{|l|c|c|c|c|}
\hline \multicolumn{1}{|c|}{ Parameter } & Unit & \multicolumn{3}{c|}{ Load } \\
\hline & & $50 \%$ & $75 \%$ & $100 \%$ \\
\hline Chemical energy of used fuel & $\mathrm{kW}$ & 1903 & 2613 & 3404 \\
\hline Electric efficiency & $\%$ & 37 & 40 & 41 \\
\hline Thermal efficiency & $\%$ & 49 & 44 & 43 \\
\hline Overall efficiency & $\%$ & 86 & 85 & 84 \\
\hline
\end{tabular}

The above results indicate that cogeneration systems are characterized by high overall efficiency of the system, which means that the thermal energy generated in the gas combustion process has been appropriately used. It was used to heat the heating water and to produce electricity. The increase in the system load has forced the increase of electrical efficiency, which is accompanied by a decrease in thermal and overall energy. In addition, during the tests at $100 \%$ load with CNG fueled, environmental measurements were carried out, showing concentration levels: $\mathrm{SO}_{2}, \mathrm{NO}_{x}$, $\mathrm{CO}$ and dust (smog) pollution contained in in the exhaust gas - Table 4 .

Table 4. Concentrations of the tested chemical compounds

\begin{tabular}{|c|c|c|c|}
\hline Tests & Parameter & Unit & $\begin{array}{c}\text { Measurement } \\
\text { results at } \\
100 \% \text { load }\end{array}$ \\
\hline \multirow{4}{*}{$\begin{array}{l}\text { Concentrations of } \\
\text { substances in ex- } \\
\text { haust gas under } \\
\text { normal conditions }\end{array}$} & $\begin{array}{c}\text { Total dust (smog) } \\
\text { including sus- } \\
\text { pended PM10 } \\
\end{array}$ & $\mathrm{mg} / \mathrm{m}^{3}{ }_{U}$ & 1.71 \\
\hline & $\mathrm{SO}_{2}$ & $\mathrm{mg} / \mathrm{m}^{3}{ }_{U}$ & 1.06 \\
\hline & $\mathrm{NO}_{\mathrm{x}}$ & $\mathrm{mg} / \mathrm{m}^{3}{ }_{\mathrm{U}}$ & 223 \\
\hline & $\mathrm{CO}$ & $\mathrm{mg} / \mathrm{m}^{3}{ }_{\mathrm{U}}$ & 38.2 \\
\hline \multirow{4}{*}{$\begin{array}{l}\text { Concentrations of } \\
\text { substances in ex- } \\
\text { haust gas converted } \\
\text { into a unit of chemi- } \\
\text { cal energy contained } \\
\text { in the fuel }\end{array}$} & $\begin{array}{c}\text { Total dust (smog) } \\
\text { including sus- } \\
\text { pended PM10 }\end{array}$ & $\mathrm{g} / \mathrm{GJ}$ & 0.87 \\
\hline & $\mathrm{SO}_{2}$ & $\mathrm{~g} / \mathrm{GJ}$ & 0.505 \\
\hline & $\mathrm{NO}_{\mathrm{x}}$ & $\mathrm{g} / \mathrm{GJ}$ & 106 \\
\hline & $\mathrm{CO}$ & $\mathrm{g} / \mathrm{GJ}$ & 18.2 \\
\hline
\end{tabular}

From the results presented in the Table 4, it can be concluded that the use of natural gas as fuel for the engine is a pro-ecological solution. Values of concentration of nitrogen oxides $\left(\mathrm{NO}_{\mathrm{x}}\right.$ expressed as the sum of nitric oxide (NO) and nitrogen dioxide $\left(\mathrm{NO}_{2}\right)$, carbon monoxide and total dust are within the limits of allowed concentrations of pollutants emitted into the air $\left(\mathrm{NO}_{\mathrm{x}}<300 \mathrm{mg} / \mathrm{m}^{3}{ }_{\mathrm{u}}, \mathrm{CO}<100 \mathrm{mg} / \mathrm{m}^{3}{ }_{\mathrm{u}}\right.$ and total dust $<50 \mathrm{mg} / \mathrm{m}^{3}$ ) and are definitely below the concentration values for fuels like gasoline or diesel $[4,10]$.

Similar conclusions can be obtained by analyzing another parameter, i.e. $\mathrm{NO}_{\mathrm{x}}$ specific emissions, which is 2.33 $\mathrm{kg} / \mathrm{h}$ and which is lower than the permissible value of 5.54 $\mathrm{kg} / \mathrm{h}$ according to the permit of the Chief Inspectorate for Environmental Protection for the introduction of gaseous and particulate matter into the air.

\section{Cogeneration system in a vessel}

The concept of using the tested engine in a vessel and creating a cogeneration system for such a unit is an alternative to typical technical solutions currently used in the construction of vessels. Such a system would primarily provide the drive for the selected unit, through appropriate translation and coupling with the propeller. In addition, a gas engine coupled with a properly selected generator would provide the unit with power supply for its own needs (lighting, power for on-board devices). Another functionality of the cogeneration system is the use of waste heat coming from the engine cooling system, to heat the deck and to heat utility water.

When using coolant for cooling the engine block, cylinder heads, lubricating oil, intercooler, a certain amount of thermal energy is obtained. In the water-water type exchanger, the coolant gives off heat to drinking water, which circulates in a closed circuit and supplies heat consumers in individual rooms of the vessel. The heating system on the unit will consist of a supply and return piping system, shutoff and regulating fittings, sludge, filters, heat receivers and compensating vessels. The expansion vessels are mainly used for safety reasons, they are to protect the system from pressure increase. Unlike air, water has better thermal and flow properties. With this type of installations it is possible to use smaller cross-sections of pipes, which creates better conditions for heat exchange. Energy obtained in a cogeneration system can also be properly stored and used at a later time. The storage possibility is created, for example, by a buffer exchanger filled with water. By using the buffer it is possible to take in any amount of heat when there is such a need with small losses during the liquid flow. The buffer tank consists of coils, shut-off and regulating fittings and measuring devices that ensure that the set temperature is maintained.

Waste gas is another important source of waste heat. The use of a suitable tube-type or plate-type exhaust gas-air exchanger will make it possible to use the thermal energy contained in the exhaust gases to heat the deck spaces. The exhaust gases leaving the engine cylinders give the heat to the air, which will be used to heat the rooms. The exhaust gases are characterized by high temperature as well as the content of toxic compounds. This requires appropriate materials for the construction of the exchanger, which will ensure its tightness and enable operation in high temperature and acidic environment, which may arise at the moment of condensation of water vapor contained in the exhaust and reaction with sulfur or nitrogen oxides $[1,7,12]$.

\section{Summary}

Cogeneration systems are mainly used in industrial power plants (combined heat and power plants), but based on the analysis carried out in this publication, that suitably adapted and selected devices will prove themselves on board of ships. A number of arguments have been obtained for using the indicated gas engine in a vessel. The cogeneration system guarantees high overall efficiency, as shown in the example of the cogeneration unit under study, for which the value of general efficiency was above $80 \%$. Without waste energy management, the efficiency of the engine alone is only $38 \%$. 
The data and parameters collected during the cogeneration system tests were not referred to the actual watercraft with specific dimensions and the expected speed of movement of the unit, as well as no external conditions were identified in which the unit would work (fairway width, river depth, etc.). Nevertheless, the $1435 \mathrm{~kW}$ engine with a swept volume of $60 \mathrm{dm}^{3}$, powered by natural gas, presented in this paper, seems to be an interesting alternative to currently used engines in vessels. This is supported by favorable emission and toxicological parameters, especially when compared to the parameters of engines fueled by marine fuel. Fuel of this type contains in its composition significant amounts of sulfur, which results in increased emission of sulfur oxides, during its combustion. Therefore, the use of alternative fuels in water transport, such as natural gas, can ensure the maintenance of working conditions in accordance with the applicable emission standards. In addition, the use of natural gas can mean financial benefits while maintaining the current level of the unit price of this fuel.

\section{Nomenclature}

\begin{tabular}{|c|c|c|c|}
\hline $\mathrm{CNG}$ & compressed natural gas & Q & torque on the cone \\
\hline $\mathrm{E}_{\mathrm{G}}$ & chemical energy of gaseous fuel & $\mathrm{Q}_{\mathrm{E}}$ & thermal power of the system \\
\hline $\mathrm{HT}$ & engine & $\mathrm{Q}_{\mathrm{n}}$ & heat delivered \\
\hline LNG & liquefied natural gas & $\mathrm{R}$ & towing resistance \\
\hline LT & intercooler & $\mathrm{T}$ & thrust \\
\hline $\mathrm{n}$ & shaft rotation speed & $\mathrm{v}_{\mathrm{A}}$ & speed \\
\hline $\mathrm{n}_{\mathrm{n}}$ & engine speed & $\mathrm{V}_{\mathrm{G}}$ & gas fuel flow \\
\hline $\mathrm{n}_{\mathrm{s}}$ & propeller speed & $\mathrm{W}_{\mathrm{d}}$ & calorific value of gas fuel \\
\hline PM10 & particulate matter (size 10$)$ & $\eta_{0}$ & overall system efficiency \\
\hline $\mathrm{P}_{\mathrm{B}}$ & power generated & $\eta_{c}$ & thermal efficiency of the system \\
\hline $\mathrm{P}_{\mathrm{D}}$ & power delivered to the propeller & $\eta_{E}$ & electric efficiency of the system \\
\hline $\mathrm{P}_{\mathrm{E}}$ & electric power at the generator terminals & $\eta_{e}$ & efficiency of the drive system \\
\hline $\mathrm{P}_{\mathrm{T}}$ & thrust power & $\eta_{G}$ & efficiency of the shaft lines \\
\hline
\end{tabular}

\section{Bibliography}

[1] ABRAMEK, K.F., UZDOWSKI, M. Wybrane aspekty eksploatacji pojazdów wykorzystujących paliwa gazowe. Autobusy. Technika, Eksploatacja, Systemy Transportowe 2012, 13(4), 39-42.

[2] GIERNALCZYK, M. Metoda określania zapotrzebowania energii do napędu statku, energii elektrycznej i wydajności kotłów dla nowoczesnych statków pasażerskich przy wykorzystaniu metod statystycznych. Akademia Morska w Szczecinie, Zeszyty Naukowe. 2008, 14(86), 9-13.

[3] KACPERCZYK, R. Środki transportów część 1. DifinEdukacja. Warszawa 2012.

[4] KORDYLEWSKI, W. Spalanie i paliwa - wydanie IV. Oficyna Wydawnicza Politechniki Wrocławskiej. Wrocław 2005.

[5] KULCZYK, J. Śródlądowy transport wodny. Oficyna Wydawnicza Politechniki Wroctawskiej. Wrocław 2003.

[6] LEJDA, K., JAWORSKI, A. LNG Alternatywne paliwo przyszłościowe dla autobusów miejskich. Zeszyty NaukowoTechniczne Oddziału Krakowskiego SITK. 1999, 31(70).

[7] MERKISZ, J. Ekologiczne problemy silników spalinowych, Wydawnictwo Poltechniki Poznańskiej. Poznań 1998.

[8] MERKISZ, J., PIELECHA, J., RADZIMIRSKI, S. Emisja zanieczyszczeń motoryzacyjnych w świetle nowych przepisów Unii Europejskiej. WKE. Warszawa 2012.

[9] MIŁASZEWICZ, D., OSTAPOWICZ, B. Warunki zrównoważonego rozwoju transportu w świetle dokumentów

Zbigniew J. Sroka, DSc., DEng. - Faculty of Mechanical Engineering, Wroclaw University of Science and Technology.

e-mail: zbigniew.sroka@pwr.edu.pl w UE. Studia i Prace Wydziału Nauk Ekonomicznych i Zarządzania. Wydawnictwo Naukowe Uniwersytetu Szczecińskiego. 2011, 24.

[10] MYŚKÓW, M. Prognozowanie emisji związków toksycznych w spalinach opalanych pomocniczych kotłów okrętowych. Zeszyty Naukowe Akademii Morskiej w Szczecinie. 2005, 5(77).

[11] PRZYBYŁA, G. Wpływ paliw gazowych na parametry pracy silnika tłokowego silnika spalinowego pracującego w układzie CHP. Biblioteka Źródłowej Energetyki Prosumenckiej. 2014.

[12] SKOREK, J. Gazowe układy kogeneracyjne. WNT. Warszawa 2005.

[13] WITKOWSKI, K. Problematyka zanieczyszczenia atmosfery przez statki wykorzystywane w transporcie morskim. Autobusy - Bezpieczeństwo i Ekologia. 2016, 6, 468-473.

[14] WOŁOSZYN, R. Gaz ziemny jako paliwo silnikowe. Autobusy. 2007, 5, 18-21.

[15] Ministerstwo Gospodarki Morskiej i Żeglugi Śródlądowej, Założenia do planów rozwoju śródlądowych dróg wodnych w Polsce na lata 2016-2020 z perspektywą do roku 2030, Dokument przyjęty przez Radę Ministrów 14 czerwca 2016.

[16] Instrukcja obsługi agregatu kogeneracyjnego CumminsHECG1400-GZ.

Karolina Buczma, BEng. - Faculty of Mechanical Engineering, Wroclaw University of Science and Technology.

e-mail:214073@student.pwr.edu.pl 